\title{
Astrocyte Aquaporin Dynamics in Health and Disease
}

\author{
Maja Potokar ${ }^{1,2,+}$, Jernej Jorgačevski ${ }^{1,2, \dagger}$ and Robert Zorec ${ }^{1,2, *}$ \\ 1 Laboratory of Neuroendocrinology-Molecular Cell Physiology, Institute of Pathophysiology, \\ Faculty of Medicine, University of Ljubljana, Zaloška 4, 1000 Ljubljana, Slovenia; \\ maja.potokar@mf.uni-lj.si (M.P.); jernej.jorgacevski@mf.uni-lj.si (J.J.) \\ 2 Celica Biomedical, Tehnološki Park 24, 1000 Ljubljana, Slovenia \\ * Correspondence: robert.zorec@mf.uni-li.si; Tel.: +386-1543-7020; Fax: +386-1543-7036 \\ + These authors contributed equally to this work. \\ Academic Editor: Kenichi Ishibashi \\ Received: 26 May 2016; Accepted: 7 July 2016; Published: 13 July 2016
}

\begin{abstract}
The family of aquaporins (AQPs), membrane water channels, consists of diverse types of proteins that are mainly permeable to water; some are also permeable to small solutes, such as glycerol and urea. They have been identified in a wide range of organisms, from microbes to vertebrates and plants, and are expressed in various tissues. Here, we focus on AQP types and their isoforms in astrocytes, a major glial cell type in the central nervous system (CNS). Astrocytes have anatomical contact with the microvasculature, pia, and neurons. Of the many roles that astrocytes have in the CNS, they are key in maintaining water homeostasis. The processes involved in this regulation have been investigated intensively, in particular regulation of the permeability and expression patterns of different AQP types in astrocytes. Three aquaporin types have been described in astrocytes: aquaporins AQP1 and AQP4 and aquaglyceroporin AQP9. The aim here is to review their isoforms, subcellular localization, permeability regulation, and expression patterns in the CNS. In the human CNS, AQP4 is expressed in normal physiological and pathological conditions, but astrocytic expression of AQP1 and AQP9 is mainly associated with a pathological state.
\end{abstract}

Keywords: astrocyte; glia; aquaporin (AQP); aquaporin isoforms; orthogonal arrays of particles (OAPs); brain edema

\section{Water Homeostasis, Brain Edema, and Astrocytes}

Water homeostasis in the central nervous system (CNS) is tightly regulated, as even minute changes in extracellular volume affect ion concentrations and, consequently, neuronal excitability [1]. Dysregulated distribution of water in the neural tissue often occurs in brain tumors, brain abscess, meningitis, stroke, and neurotrauma, when brain edema forms and often worsens the outcome of these disorders [2,3]. As the brain is encapsulated within the cranium, it has very limited space for volume enlargement during brain edema. Therefore, mechanisms for efficient and quick redistribution of water within the brain parenchyma are essential for normal neuronal function. Such mechanisms are still largely unclear and, therefore, the possibilities for medical intervention when brain edema develops are limited. Vasogenic edema, which is amenable to treatment, results mainly from increased permeability of the blood-brain barrier [4], whereas cytotoxic edema results from cellular swelling, mainly caused by failure of energy metabolism [3]. Although cell swelling can be, at least in part, attenuated by adrenergic stimulation [5], currently there appears to be no efficient treatment for this event.

Astrocytes are the only cells in the CNS that undergo rapid changes in volume [6-8]. These cells populate the gray and white matter of the CNS and are, arguably, the most heterogeneous (in form and function) type of glia $[9,10]$. Astrocytes can be broadly defined as primary homeostatic cells of the brain responsible for a wide variety of functions that include, for example, regulation of synaptogenesis, synaptic maturation, neurotransmitter homeostasis, brain microcirculation, brain 
metabolism, and control over the formation and maintenance of the blood-brain barrier [8,11-23]. All of these processes depend, to a large extent, on the mechanisms by which astrocytes communicate with the surrounding cells. These include plasma membrane channels, receptors, transporters, and mechanisms that mediate the exchange of molecules by exo- and endocytotic processes [24-30]. Exo- and endocytotic processes involve vesicles, from which signaling molecules are released in the extracellular space, or membrane channels, such as aquaporins (AQPs), that are integrated in the plasma membrane. Both exo- and endocytotic vesicles are mobile in the cytoplasm [31,32] and their mobility is altered under pathologic conditions [33,34].

Non-neuronal cells, which include astrocytes, outnumber neurons in some areas in the CNS, such as the neocortex [35]. Astrocytic abundance in these areas and their anatomical occupancy of non-overlapping territories between other glial cells, neurons, and endothelial cells of the vasculature [11,13-15,36,37], places them ideally to enhance transport of molecules across the brain parenchyma, including the transport of water. In addition to extensive research on astrocytes in several fields, such as ion and $\mathrm{pH}$ homeostasis, metabolic support to neurons, and modulation of synaptic strength, their role in the regulation of brain water homeostasis is also a topic of interest. Namely, in astrocytes, specialized membrane proteins have been identified that allow fast transmembrane flux of water [38-40].

\section{Aquaporin Types and Their Isoforms in Astrocytes}

AQPs have been identified in multiple mammalian tissues as well as in invertebrates, plants, and microbes [41]. As their name suggests, APQs are proteins that are specialized in water transport across the plasma membrane of cells, although they are also involved in several other functions [39]. The plasma membrane, per se, is permeable to water molecules, which pass between the intracellular and extracellular space. However, such passive transport is slow, highlighting the need for specialized transmembrane water channels, AQPs, which allow several orders of magnitude higher rates of facilitated transmembrane water flux in the direction of greater osmolality. All AQPs are small hydrophobic proteins, composed of six non-polar bilayer-spanning domains, interconnected by loops A to E (this general description of AQPs structure is evident in the schematic representation of AQP4 depicted in the Figure 1). According to the hourglass model, the conserved loops B and E are essential for the water pore [39,42-44]. To date, $13 \mathrm{AQP}$ types have been characterized in mammalian cells; three types, AQP1, AQP4, and AQP9, have been confirmed in the CNS [45]. They differ in their permeability properties (Table 1) and have different distribution patterns. AQP1 and AQP4 are categorized as "pure" aquaporins, water channels primarily only permeable to water, whereas AQP9 is an aquaglyceroporin, permeable to water and to small solutes, such as glycerol and urea [45]. AQP1 was the first AQP discovered in the CNS, identified in the epithelium of the choroid plexus and later also in human astrocytes [46,47]. The most abundant AQP in the mammalian brain is AQP4, which is predominantly localized in astrocytes that are in direct contact with capillaries and pia. AQP4 is not confined solely to astrocytes; it has also been found in subpopulations of ependymal cells [40]. The distribution of AQP9 in the brain is unique; it has been identified in ependymal cells lining the ventricles and in tanycytes of the mediobasal hypothalamus. AQP9 is also present in astrocytes, in endothelial cells of pial vessels, and almost exclusively in catecholaminergic neurons [48-50].

The strategic anatomical position of astrocytes with regard to water transport is, therefore, mirrored in the fact that all three CNS AQPs are expressed in these cells. We review these AQP types and their isoforms in respect of their expression patterns, intracellular localization, permeability regulation, and their role in normal physiological and pathological conditions. 

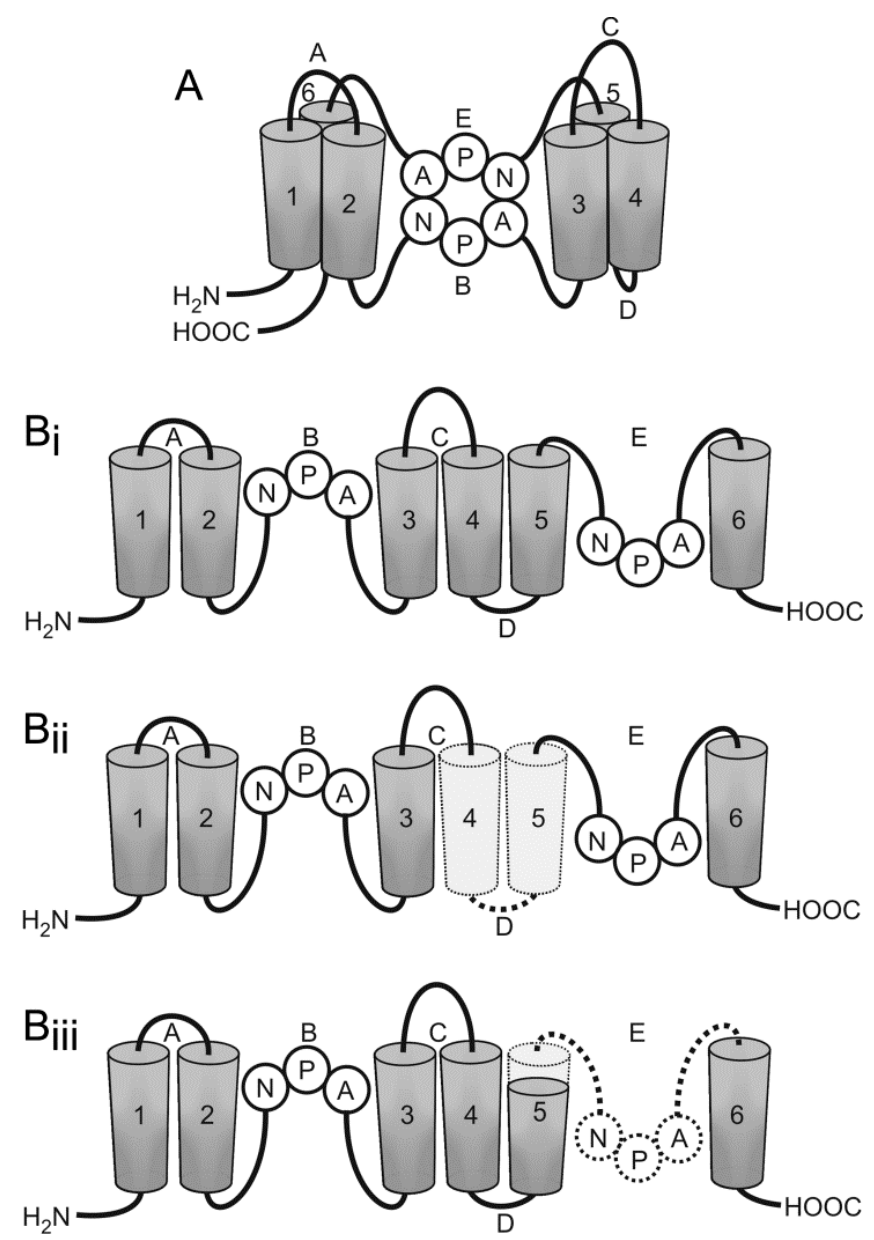

Figure 1. Aquaporin 4 (AQP4) isoforms differ in structure. (A) The proposed hourglass model of AQP4. Loops B and E contain NPA motifs (Asn-Pro-Ala), which form an aqueous pore in the membrane bilayer; and (B) schematic representations of the AQP4 channel and its isoforms. (i) AQP4a, AQP4c, and AQP4e have six bilayer-spanning domains (1-6) and five interconnecting loops (A-E); (ii) AQP4b, AQP4d, AQP4f isoforms lack helices 4 and 5 together with their interconnecting loop D; and (iii) AQP4- $\triangle$ isoform lacks the final part of helix 5 and loop $\mathrm{E}$.

Table 1. Aquaporin (AQP) types in astrocytes.

\begin{tabular}{|c|c|c|c|c|}
\hline AQP Type & AQP Isoforms & $\begin{array}{l}\text { Permeability } \\
\text { to Water }\end{array}$ & $\begin{array}{l}\text { Permeability to Small Solutes (i.e., } \\
\text { Glycerol, Urea, Monocarboxylates) }\end{array}$ & $\begin{array}{l}\text { Ability to Form OAPs in } \\
\text { the Plasma Membrane }\end{array}$ \\
\hline AQP1 & AQP1 & Yes & No & No \\
\hline \multirow{6}{*}{ AQP4 } & AQP4a (M1) & Yes & No & Only together with AQP4c \\
\hline & AQP4c (M23) & Yes & No & Yes \\
\hline & AQP4e & Yes & No & Only together with AQP4c \\
\hline & $\mathrm{AQP} 4 \mathrm{~b}$ & $?$ & No & N/A \\
\hline & AQP4d & $?$ & No & N/A \\
\hline & $\mathrm{AQP} 4 \mathrm{f}$ & $?$ & No & $\mathrm{N} / \mathrm{A}$ \\
\hline \multirow[t]{2}{*}{ AQP9 } & $\begin{array}{l}\text { AQP9 } 32 \mathrm{kDa} \\
\text { (is AQP9 } \sim 30 \\
\text { kDa its splicing } \\
\text { isoform?) }\end{array}$ & Yes & Yes & No \\
\hline & AQP9 25 kDa & Yes & Yes & No \\
\hline
\end{tabular}

?, not yet definitely determined; N/A, not applicable; OAPs, orthogonal arrays of particles. 


\subsection{Aquaporin 1}

2.1.1. Aquaporin 1 (AQP1) in the Central Nervous System (CNS): Expression in Physiological and Pathological Conditions

The AQP1 channel is primarily a water pore to facilitate transmembrane transport of water molecules driven by osmotic gradients [51]. AQP1 was the first AQP to be identified, initially found in erythrocytes and renal tubules [38,52-54]. Its expression was also confirmed in other tissues as shown in Table 2. In the CNS, AQP1 was first detected in rat choroid plexus epithelial cells where it is restricted to their apical microvilli [55]. Its distribution in the choroid plexus epithelium (CPE) implied a role in the secretion of cerebrospinal fluid (CSF) into ventricles, which was subsequently confirmed [51,55-58].

Table 2. The expression of AQP1 in different cells.

\begin{tabular}{ll}
\hline Cell Type & Reference \\
\hline Erythrocytes & {$[53]$} \\
\hline Renal epithelial cells & {$[53]$} \\
\hline Endothelial cells (except central nervous system (CNS)) & {$[55]$} \\
\hline Epithelial cells of the choroid plexus & {$[55,59]$} \\
\hline $\begin{array}{l}\text { Epithelial cells of the iris, ciliary body, lens, trachea, kidney, colonic crypt, sweat glands, } \\
\text { pancreatic acini, gallbladder epithelium, placental syncytial trophoblast cells }\end{array}$ & {$[55,59]$} \\
\hline Sensory nerve fibers in the dorsal horn of the spinal cord and the trigeminal sensory ganglia & {$[60,61]$} \\
\hline $\begin{array}{l}\text { Reactive astrocytes (human CNS) in Alzheimer disease, Creutzfeldt-Jakob disease, multiple } \\
\text { sclerosis, and in ischemic lesions }\end{array}$ & {$[47,62]$} \\
\hline $\begin{array}{l}\text { Astrocytes (non-human primate CNS, a subpopulation of white matter astrocytes in Macaca } \\
\text { fascicularis) }\end{array}$ & {$[63]$} \\
\hline Schwann cells (Macaca fascicularis CNS) & {$[63]$} \\
\hline Trigeminal nerve fibers (Macaca fascicularis CNS) & {$[63]$} \\
\hline Neurons on the surface of the pial blood vessels (Macaca fascicularis CNS) & {$[63]$} \\
\hline Vascular smooth muscle cells & {$[64]$} \\
\hline
\end{tabular}

In addition to the CPE, the expression of AQP1 was also confirmed in CNS astrocytes. However, in human astrocytes, its expression is mainly restricted to neuropathologic conditions, e.g., multiple sclerosis (MS), Alzheimer disease (AD), Parkinson disease (PD), and amyotrophic lateral sclerosis $[47,62,65]$. AQP1 in astrocytes has been detected in astrocytomas in subarachnoid hemorrhage tissue, in Creutzfeldt-Jakob disease (CJD), in bovine and murine spongiform encephalopathy, and in a rat epilepsy model [66-70]. Initially, no AQP1 was found in the healthy human neocortex [66], but it was later reported that a minor population of astrocytes expresses AQP1 in a neurologically normal brain [47].

In human astrocytes, the expression of AQP1 is almost exclusively restricted to pathologic CNS tissue, but it has been detected in a healthy non-human primate brain of the Macaca fascicularis monkey [63]. Therefore, in at least some primates, astrocytic AQP1 plays an important role in the regulation of water homeostasis in the CNS in non-pathological brain. This role remains to be further elucidated.

What do we know about the intracellular distribution of AQP1 in astrocytes? In cultured human astrocytes, AQP1 was found co-expressed with AQP4 [47]. The detailed intracellular distribution of AQP1 remains to be thoroughly addressed, but it appears that its localization in cultured astrocytes is not exclusive to the plasma membrane; it is also present in the cytoplasm and likely in the nuclear membrane $[47,69]$. Its abundant intra-astrocyte distribution in cultured cells may be, in part, 
the consequence of the in vitro conditions, which differ from those in intact tissue, as was observed also for AQP4 [71,72].

However, variable intracellular distribution in astrocytomas has also been described. In low-grade astrocytomas, AQP1 immunoreactivity was present mostly in the plasma membrane, whereas in high-grade astrocytomas, massively-upregulated AQP1 was also distributed throughout the cytoplasm [70]. In addition to the variable intra-astrocytic distribution of AQP1, the expression of AQP1 also varies among different types of astrocytes, as was shown in intact CNS tissue. High expression of AQP1 was detected in highly-branched fibrillary astrocytes, whereas expression was low in poorly-branched protoplasmic and hypertrophic astrocytes. For example, this pattern was observed in MS and AD brain $[47,62]$. In both cases, AQP1 expression was observed in highly-branched fibrillary astrocytes positioned around blood vessels and neurons in tissue showing degenerative changes. In the MS brain, such astrocytes were present in chronic active demyelinating lesions and in the AD brain, they were in close proximity to $\beta$-amyloid plaques. Reactive astrocytes in pathological brain parenchyma can express AQP1, AQP4, or both, as was demonstrated in the tissue section of the motor cortex in a patient with PD [62]. In addition, in AD brain, increased expression of AQP1 in astrocytes has been observed only in the early stages of AD $[65,69]$. Therefore, the expression of AQP1 in human pathological CNS astrocytes appears to be spatially and temporally regulated.

The upregulation of AQP1 may have a pivotal role in the maintenance of water homeostasis in the CNS under pathologic conditions; however, detailed mechanisms remain to be elucidated [70].

\subsubsection{Water Permeability of AQP1}

Most of the data on the regulation of AQP1 water permeability comes from studies on Xenopus oocytes; AQP1 regulation in astrocytes remains to be determined. In general, water permeability through AQP1 may be regulated at several levels. One of them is phosphorylation. AQP1 has four potential phosphorylation sites that can be phosphorylated by protein kinase A (PKA), protein kinase $\mathrm{C}$ (PKC), and calmodulin-dependent kinase II (CKII). These phosphorylation sites are conserved in humans, rats, and mice [73]. Several contradictory results have been reported regarding the effect of AQP1 phosphorylation on water permeability in Xenopus oocytes. Phosphorylation of AQP1 by PKA and PKC was reported to increase water channel permeability in Xenopus oocytes [74,75], but others reported that phosphorylation by PKA or PKC did not affect water permeability of aquaporins 1-5 [76]. In addition to kinases, atrial natriuretic peptide (ANP) and arginine vasopressin (AVP) have also been shown to modulate water permeability of AQP1 in transfected Xenopus oocytes. AVP has been shown to increase and ANP to decrease membrane water permeability [77].

Water permeability of AQP1-expressing cells may also be related to AQP1 redistribution to the plasma membrane. Such cAMP-dependent redistribution of AQP1 has been demonstrated in Xenopus oocytes [74]. Similarly, in rat cholangiocytes, increased insertion of AQP1 in the apical membrane triggered by microtubule-dependent secretin was observed [78]. In addition to short-term regulation, long-term regulation of AQP1 water permeability is also important [73]. Both aspects of regulation in astrocytes are still unclear.

\subsection{Aquaporin 4}

\subsubsection{AQP4 in the CNS: Expression in Physiological Conditions}

AQP4 was first cloned from rat lung and then identified in different tissues (Table 3) [79,80]. It is predominantly expressed in the brain, where it is also the most abundant water channel $[39,40,42]$. A subpopulation of ependymal cells lining the ventricles also expresses AQP4, but the principal site of AQP4 expression in the CNS is astrocytes [40,80-82]. The highest levels of AQP4 expression were recorded in astrocytes along the subarachnoid space, ventricles, blood vessels, and in areas for osmosensation and regulation of body water balance, including the supraoptic nucleus and subfornical organ [40]. Particularly enriched expression of AQP4 occurs in astrocytes in contact 
with capillaries and pia, indicating that this AQP4 expression is associated with brain-blood or brain-liquor interfaces $[40,63]$. In addition, AQP4 is also found on astrocytic processes around synapses. Astrocytes enwrapping distinct types of synapses express different amounts of AQP4, i.e., strong immunoreactivity was found in the glial processes in contact with parallel fiber synapses on Purkinje cell dendritic spines, whereas in other synapses astrocyte processes were modestly labeled $[40,83,84]$.

Table 3. The expression of AQP4 in different cells.

\begin{tabular}{ll}
\hline Cell Type & Reference \\
\hline Astrocytes (brain and spinal cord) & {$[42,79,80,85]$} \\
A subpopulation of brain ependymal cells & {$[40,80,81,85]$} \\
Retina, iris, ciliary body & {$[79,81,82]$} \\
Lung epithelial cells & {$[79,81]$} \\
Renal basolateral plasma membrane of collecting duct principal cells, renal papillary vasa recta & {$[79,81]$} \\
Colon (villus) epithelial cells & {$[81]$} \\
Stomach parietal cells & {$[80]$} \\
Excretory tubules of salivary and lacrimal glands & {$[80]$} \\
Auditory epithelium of the organ of Corti & {$[86,87]$} \\
Skeletal muscle; the sarcolemma of fast-twitch fibers & {$[80,88]$} \\
\hline
\end{tabular}

\subsubsection{Intracellular Distribution of AQP4}

In general, the intracellular distribution of AQP4 in astrocytes is distinctly polarized, predominantly concentrated in the plasma membrane of glial processes close to or in direct contact with blood vessels, the ependymal layer, and pia $[40,85]$. However, in distinct osmosensory areas, glial processes show little or no polarization of AQP4 distribution [40]. A similar observation was described for rat and mouse astrocyte cultures, where immunolabeling of AQP4 revealed an intracellular and plasma membrane pattern [71,72]. The strong intracellular pattern observed in cultured murine astrocytes may also be a consequence of the extracellular milieu that is altered in comparison with that in intact tissue. By different experimental manipulation, localization of AQP4 in the plasma membrane significantly increased in stellation-induced rat astrocytes [71] and in astrocytes plated on a basement membrane matrix consisting mainly of laminin [72].

Several AQP4 isoforms are recognized in astrocytes (AQP4a-f; Table 4), but the description of AQP4 intracellular distribution is more complex $[42,89,90]$. The intracellular localization of individual AQP4 isoforms is well described for the two most studied isoforms, AQP4a (M1) and AQP4c (M23), but it is still poorly investigated for other isoforms. Briefly, to date, seven isoforms of AQP4 water channel have been described; AQP4a-f, which were all detected in astrocytes, and AQP4- $\Delta[89,91]$. The first two AQP4 isoforms to be described in humans, rats, and mice are AQP4a (M1) and AQP4c (M23), which are alternative transcripts from two different initiating methionine sites [42,79,90,92,93]. In rat $\mathrm{CNS}$, the shorter $\mathrm{AQP} 4 \mathrm{c}(\mathrm{M} 23 ; 32 \mathrm{kDa})$ isoform was shown to be more abundant than the longer AQP4a (M1; $34 \mathrm{kDa})$ isoform $[90,94]$.

Table 4. AQP4 isoforms.

\begin{tabular}{llll}
\hline $\begin{array}{l}\text { AQP4 } \\
\text { Isoforms }\end{array}$ & Cell Type & Intracellular Localization & Reference \\
\hline AQP4a (M1) & Astrocytes & PM & {$[85,90,95]$} \\
AQP4c (M23) & Astrocytes, skeletal muscle, kidney & PM & {$[85,90,95]$} \\
AQP4e (Mz) & Astrocytes (rat), organ of Corti (rat) & PM, intracellular vesicles, GA, EC & {$[72,89,96]$} \\
AQP4b & Astrocytes (rat) & GA & {$[89]$} \\
AQP4d & Astrocytes (rat) & GA, EC & {$[72,89]$} \\
AQP4f & Astrocytes (rat) & GA & {$[89]$} \\
AQP4- $\Delta$ & Skeletal muscle & ER, faintly in the PM & {$[91]$} \\
\hline
\end{tabular}

PM, plasma membrane; ER, endoplasmic reticulum; EC, late endosomal compartments; GA, Golgi apparatus. 
A thorough mapping of the rat $A Q P 4$ gene revealed four additional isoforms besides the two classic isoforms: AQP4a (M1) and AQP4c (M23) [89]. Hence, a new uniform terminology was proposed. $\mathrm{M} 1$ and M23 were renamed as AQP4a and AQP4c, respectively, and additional isoforms were named AQP4b, AQP4d, AQP4e (also termed Mz isoform [96]), and AQP4f [89]. The AQP4e-sized (36 kDa) isoform was later confirmed in mice, pigs, and humans [97]. Plasma membrane water-permeable isoforms AQP4a, AQP4c, and AQP4e are basic isoforms, whereas AQP4b, AQP4d, and AQP4f are their alternative splicing variants [89]. The latter three isoforms have so far been shown to be intracellular, and, based on their structure, it is hypothesized that they are unlikely to transport water. All three isoforms lack exon 2, which is why they have only four transmembrane helices; the other three isoforms all have all six (Figure 1). They lack helices 4 and 5 together with their interconnecting loop D, which is one of the stabilizing factors of AQP4. When transfected into Xenopus oocytes, they failed to enhance water permeability through their plasma membrane [89]. However, this is not entirely surprising, given their likely intracellular localization.

Different AQP4 isoforms have distinct localization at the subcellular level. AQP4a (M1) and AQP4c (M23) are predominantly localized at the plasma membrane of perivascular endfeet regions of astrocytes. Although, in addition to their strong distribution in the plasma membrane, intracellular localization was also observed in cultured astrocytes $[85,90,95]$. Localization of AQP4e in the plasma membrane has already been confirmed in rat brain lysates, Xenopus oocytes, HeLa cell lines, human malignant glioblastoma cell lines, and in primary cultured rat astrocytes $[72,89,96,98]$. The abundance of its expression in the plasma membrane of astrocytes appears to be dynamic, affected by the osmolality of the extracellular milieu [72]. In addition to the plasma membrane, internal AQP4e localization has also been observed in HeLa cell lines, as well as cultured rat astrocytes, consistent with the recycling of AQP4 $[72,89,99]$. Intracellularly, the AQP4e isoform was found in the Golgi apparatus (GA) and in late endosomal degradation compartments [72]. Moreover, it was also observed in highly dynamic vesicles, the mobility of which was impaired in a model of reactive gliosis and at high levels of intracellular concentration of calcium ions. In hypo-osmotic conditions, mimicking cell edema, the mobility of vesicles carrying the AQP4e isoform changed in different intervals after hypo-osmotic stimulation and was inversely correlated with the abundance of AQP4 at the plasma membrane. Decreased mobility overlapped with increased plasma membrane localization [72].

$\mathrm{AQP} 4 \mathrm{~b}, \mathrm{AQP} 4 \mathrm{~d}$, and AQP4f isoforms remained situated intracellularly when expressed in Xenopus oocytes and in HeLa cells and all of them were shown to colocalize with GA and showed a broader cytoplasmic distribution [89]. In cultured astrocytes, AQP4d was also detected intracellularly in GA and in late endosomal degradation compartments [72]. To understand the role of the intracellular AQP4 isoforms in astrocytes, especially those newly detected, there is a need to systematically investigate their subcellular localization and function.

In addition to AQP4b, AQP4d, and AQP4f, another intracellular AQP4 isoform was described in skeletal muscle. This is alternatively spliced transcript named AQP4- $\Delta 4$ that lacks exon 4 . AQP4- $\Delta 4$ lacks the final part of transmembrane helix 5 and loop E, which contains the second asparagine-proline-alanine (NPA) motif essential for the formation of the structural domain for water permeation in the aquaporin monomeric channel (Figure 1). NPA motifs form the loops connecting helices 2 and 3 , and 5 and 6 , on the opposite sides of the membrane bilayer [42,91,100,101]. AQP4- $\Delta 4$ shows no water transport properties in HeLa cells and was shown to reside in the ER, although a minor amount of AQP4- $\Delta 4$ was detected at the plasma membrane. AQP4- $\Delta 4$ was proposed to downregulate the expression and activity of AQP4, which likely originates from a dominant-negative effect caused by heterodimerization between AQP4 and AQP4- $\Delta 4$ [91]. Similar to the intracellular AQP4 isoforms, several other aquaporins are localized in intracellular membrane compartments, such as AQP2, AQP6, AQP8, AQP10, and AQP11 [102-107]. 


\subsubsection{Orthogonal Arrays of Particles}

A unique property of the AQP4 water channel is the formation of higher-order structures in the plasma membrane. First, monomers assemble into tetramers, which then aggregate into larger structures called orthogonal arrays of particles (OAPs) [108]. OAPs have been identified in several mammalian tissues and have been named in line with their appearance (orthogonal lattices) when visualized by freeze-fracture electron microscopy [109]. OAPs of AQP4 have been observed in astrocytes, trachea, sarcolemma, gastric parietal cells, kidney principal cells, ciliary body, and the intestine [80]. In the CNS, extensive OAPs are found in perivascular astrocyte endfeet and in astrocyte processes of the glia limitans beneath the pia $[85,94,110]$. Here, AQP4 tetramers $(4-6 \mathrm{~nm}$ in size) are mostly (>90\%) present as OAPs [94]. OAPs in astrocytes are formed from at least two AQP4 isoforms, AQP4a (M1) and AQP4c (M23). Although AQP4c (M23) has the intrinsic ability to form OAPs alone through specific intermolecular $\mathrm{N}$ terminus interactions, AQP4a (M1) can form OAPs only when expressed together with AQP4c (M23). OAPs assembled from AQP4a and AQP4c together are smaller than OAPs composed of AQP4c alone, showing that these two isoforms have opposing effects on OAP size [94,110-113].

In addition to AQP4a (M1) and AQP4c (M23), the AQP4e (Mz) isoform has also been proposed to assemble into OAPs, but only together with AQP4c (M23), similar to the AQP4a (M1) isoform [96,98]. There is a possibility that, in the tissue, OAPs contain all three plasma membrane water permeant isoforms, AQP4a (M1), AQP4c (M23), and AQP4e (Mz), as observed in brain lysates and in the transfected U87MG (human glioblastoma-astrocytoma) cell line [96,98]. The properties of AQP4e assembly into OAPs and the function of AQP4e in OAPs remain to be established, as well as the role of OAPs themselves. Several hypotheses have been proposed regarding the role of OAPs, including acceleration of water transport across the astrocyte plasma membrane, adhesive functions, clearance of macromolecules from brain interstitium, and optimizing gas exchange between blood and the brain $[108,114,115]$. However, none of these roles has been unequivocally confirmed.

\subsubsection{AQP4 Water Permeability Regulation in Astrocytes}

Knowledge on the water permeability of AQP4 in astrocytes is scarce. In general, it is hypothesized that water permeability through AQP4 channels can be regulated at several levels. In brief, these are phosphorylation of the channel, expression and density of AQP4 channels at the plasma membrane, the rate of AQP4-laden vesicle delivery to the plasma membrane, and aggregation of AQP4 into OAPs.

AQP4 has several potential phosphorylation sites [73], which makes the regulation of water permeability by phosphorylation plausible. However, in cultured rat astrocytes, AQP4 failed to be phosphorylated by PKA and not all of the phosphorylation sites affect water permeability, as was shown in the case of Ser111 [71,116,117]. On the other hand, activation of PKC has been shown to phosphorylate Ser180 of AQP4, which resulted in reduced water permeability and inhibition of cell migration in a glioma cell line [118]. In cultured rat astrocytes, PKC also decreased AQP4 mRNA and protein expression, probably through signal transduction [119].

Another factor that can affect water permeability through AQP4 in astrocytes is the abundance of AQP4 expression at the plasma membrane. Fast changes in the expression of AQP4 in the plasma membrane can be regulated by translocation of the channel to/from the plasma membrane via membrane-bound vesicles of the existing cellular AQP4 pool [72]. However, the possible redistribution of the AQP4 channel to/from or inside the plasma membrane has not been addressed in the tissue, where most of the AQP4 signal is observed at the plasma membrane. Changes in the expression levels of AQP4 in the plasma membrane were observed under several pathological conditions. These changes may in part involve deregulation in vesicle traffic, as in astrocytes from an AD mouse model [120]. Altered expression levels of AQP4 in pathological conditions are reviewed in detail in the following section.

It is also hypothesized that the formation of OAPs in the plasma membrane can affect water permeability of the astrocyte plasma membrane. This could be achieved through differential assembly 
of OAPs in a post-Golgi phase governed by different expression levels of the isoforms that are also tissue specific [94,115,121-124]. In addition, other factors regulating short-term OAP assembly/modifications need to be addressed.

\subsubsection{Altered Expression of Astrocytic AQP4 in Pathologic Conditions}

Under several pathologic conditions, alterations in the subcellular distribution of AQP4 and its expression levels have been reported in astrocytes. The abundance of AQP4 in the plasma membrane has been observed to either decrease or increase, and it may be linked to altered expression of the AQP4 gene or to complementary proteins. For example, an extensive decrease in the abundance of AQP4 channels in the plasma membrane was detected in the perivascular plasma membrane of astrocytes in the hippocampal area of patients with epilepsy. This decrease was attributed to decreased expression of the AQP4 anchoring protein, even though AQP4 mRNA expression increased in the same reactivated astrocytes $[125,126]$. Apparent discrepancies have been noted in several reports on AQP4 expression in the plasma membrane of patients with $\mathrm{AD}$. The reasons for the observed decreases or increases in AQP4 in the plasma membrane remain to be clarified; however, they may arise due to samples from different stages of the disease and from different brain regions. Nonetheless, increased expression of AQP4 was observed in patients with AD with or without cerebral amyloid angiopathy (CAA), where extensive AQP4 immunoreactivity was seen around blood vessels in the CSF and brain interfaces [127]. Similarly, increased AQP4 expression was detected in cortical sections of temporal lobes of patients with $\mathrm{AD}$, where AQP4 immunostaining was more intense around larger vessels or capillaries affected by CAA and it varied depending on the severity of CAA. Increased AQP4 expression was detected around senile plaques, where it was increased during early $\beta$-amyloid $(\mathrm{A} \beta)$ peptide deposits and was downregulated in the later stage of $A \beta$ plaque formation [128]. On the other hand, no differences in the level of AQP4 expression were reported after Western blotting of the frontal cortex samples from patients with $\mathrm{AD}$, although glial fibrillary acidic protein labeling revealed moderate astrogliosis $[65,69]$. Changes in the expression of AQP4 in the plasma membrane was also screened in a mouse model of $\mathrm{AD}$, where an increased concentration of AQP4 was observed in astrocytic processes in synaptic regions and a decrease in AQP4 abundance in astrocyte endfeet membranes, specifically at sites of perivascular A $\beta$ deposits [129]. Increased expression levels of AQP4 were also reported in the brain of patients with CJD, in particular in the cytoplasm of protoplasmic and fibrillary astrocytes in the cerebral cortex and white matter, respectively [69]. AQP4 immunoreactivity in astrocytes was also more abundant in brain from patients with MS, especially at the periphery of plaques [130].

In addition to neurodegenerative diseases, astrocytic AQP4 expression was upregulated in human tissue in several other pathologic conditions, such as edematous brain tumors and surrounding tissue, after subarachnoid hemorrhage, and in peritumoral tissue and ischemia $[66,131,132]$. The expression of AQP4 was increased in the astrocytic processes, but in certain examples, polarization on astrocytic endfeet was lost [66].

Taken together, an extensive decrease of AQP4 expression in epilepsy patients likely results in perturbed water and ion homeostasis, leading to an increased propensity for seizures and cognitive decline [129]. Upregulated plasma membrane expression of AQP4 is hypothesized to facilitate the transport of water through blood vessel walls, as well as pial and ependymal surface of the brain and contribute to the development of brain edema $[125,126]$.

\subsection{Aquaglyceroporin 9}

\subsubsection{AQP9 in the CNS: Expression in Physiological Conditions}

AQP9 is an aquaglyceroporin and is the least studied AQP in astrocytes. Like all aquaporins, it is permeable to water but also to small solutes. When expressed in Xenopus oocytes, human AQP9 was found to be permeable to a variety of structurally-unrelated solutes, including polyols (glycerol, mannitol, sorbitol), purines (adenine), pyrimidines (uracil and the chemotherapeutic agent 
5-fluorouracil), and urea analogs (thiourea) [133-135]. In general, the expression of AQP9 has been identified in different cell types, including astrocytes (Table 5).

In mouse brain astrocytes, expression of AQP9 was observed in the processes bordering the subarachnoid space and ventricles, in the white matter, hippocampus, hypothalamus, and lateral septum [48]. In addition, in the adult rat brain, astrocytes expressing AQP9 were detected in the white matter and gray matter [49]. AQP9 was also detected in the astrocytes of a non-human primate brain [63]. As in rodent species, AQP9 mRNA and protein were detected in other CNS cells [63]. Reports of human expression of AQP9 are scarce and are limited mainly to pathological tissue, such as astrocytomas [136,137].

Table 5. The expression of AQP9 in different cell types.

\begin{tabular}{ll}
\hline Cell Type & Reference \\
\hline $\begin{array}{l}\text { Spinal cord and brain: } \\
\text { Astrocytes, ependymal cells lining the ventricles and tanycytes, catecholaminergic neurons, } \\
\text { endothelial cells of pial vessels, Bergmann glia }\end{array}$ & {$[49,50,138]$} \\
\hline Hepatocytes & {$[50,139]$} \\
\hline Testis Leydig cells & {$[50]$} \\
\hline Epididymis stereocilia & {$[50]$} \\
\hline Spleen leukocytes & {$[50]$} \\
\hline
\end{tabular}

\subsubsection{Intracellular Distribution of AQP9}

Several AQP9 isoforms have been identified to date. For example, in astrocytes and in a subpopulation of neurons (dopaminergic neurons in the substantia nigra and ventral tegmental area) isolated from rat brain, two AQP9 isoforms have been identified: $\sim 25$ and $\sim 30 \mathrm{kDa}$ isoforms. The $\sim 30 \mathrm{kDa}$ isoform is expressed in the plasma membrane and may correspond to the liver isoform $(\sim 32 \mathrm{kDa})$ or is possibly even a splicing variant. On the other hand, the $\sim 25 \mathrm{kDa}$ isoform (obtained by alternative splicing) is expressed in mitochondria and is highly enriched in the inner mitochondrial membrane of astrocytes. Its major role could be the transport of lactic acid into the mitochondria, which would benefit cells in ischemic conditions [140].

In general, AQP9 immunostaining in astrocytes was observed in their cell bodies, in processes directed toward blood vessels, and in perivascular endfeet; so it differs from AQP4 polarized immunolabeling $[49,63]$. In contrast, AQP9 forms only tetramers in cellular membranes and not higher-order complexes like AQP4 [98].

\subsubsection{The Role of AQP9 in the CNS}

Several functions of AQP9 in the CNS have been considered. AQP9 permeability to diverse molecules implies its role in diverse processes, such as water homeostasis and energy metabolism. Among several hypotheses, it was suggested that AQP9 may facilitate clearance of lactate and glycerol from the extracellular space, as is the case in cerebral ischemia [48]. Given that it is localized in the glia limitans and tanycytes, it may also contribute to water flow in CSF between the brain parenchyma and subarachnoid space [49]. Considering that AQP9 facilitates glycerol diffusion, as reported recently, it is probably also involved in energy metabolism in the CNS. Silencing of AQP9 in cultured astrocytes induced a decrease in glycerol uptake and triggered changes in astrocyte energy metabolism by increasing the glucose uptake [141]. Further investigation is needed to elucidate the processes regulated by AQP9 in the CNS in detail.

\subsubsection{Permeability Regulation and Expression of AQP9 in Pathological Conditions}

As in the case of AQP1 and AQP4, AQP9 can be regulated through phosphorylation, although only a few studies have investigated this. Experiments in cultured rat astrocytes suggest that signal 
transduction via PKC may decrease plasma membrane expression of AQP9 through PKC activation, and increase expression of AQP9 through the PKA-dependent increase of dbcAMP [116,119].

In addition, rendered plasma membrane expression of AQP9 was reported to be influenced by changes in mRNA expression. For example, an increase in mRNA and protein expression of AQP9 has been measured in human astrocytic tumors (reaching higher values in high-grade tumors) compared with normal brain tissue [136]. Overexpression of AQP9 was also detected in mouse astrocytes in peri-infarct areas after focal transient ischemia [48].

Short- and long-term permeability regulation of AQP9 in astrocytes remains to be elucidated.

Changes in the permeability regulation and expression of AQP9 are hypothesized to play a role in the regulation of postischemia edema and in the clearance of lactate from the damaged tissue, as well as in the malignant progression of brain astrocytic tumors $[48,130]$.

\section{Conclusions}

Three different AQP types have been identified in astrocytes. The most abundant among them is AQP4, which is also the most studied AQP type in the brain. Its expression has been confirmed in human and non-human mammalian brain astrocytes in physiological and pathological conditions. Despite its recognized general role in the regulation of brain water homeostasis, several issues remain to be elucidated, especially in light of newly-described isoforms, their roles, and permeability regulation. In addition to water permeability through the plasma membrane, AQP4 may be implicated in various other roles, such as cell adhesion, gas exchange, and possibly other roles, especially if we consider the growing body of data on different isoforms. Although AQP1 and AQP9 are expressed in physiologically normal tissue of non-human mammalian brains, it appears that, in human astrocytes, they are expressed mainly in pathological conditions. AQP9 is the least studied of all AQP types in astrocytes; its localization in human brain has been unambiguously confirmed only in astrocytomas so far. Variations in astrocytic expression patterns of different AQP types and their permeability properties suggest that they have different roles in maintaining brain homeostasis that need to be elucidated from the perspective of efficient pharmacological manipulation.

Acknowledgments: This work was supported by the Slovenian Research Agency; grant numbers P3 310, J3 3632, J3 4051, J3-4146, J3 6790, J3 7605.

Author Contributions: Maja Potokar and Jernej Jorgačevski wrote the manuscript. Robert Zorec wrote and critically evaluated the manuscript. All authors read and approved the final manuscript.

Conflicts of Interest: The authors declare no conflict of interest.

\section{Abbreviations}

$\begin{array}{ll}\text { AQP } & \begin{array}{l}\text { aquaporin } \\ \text { orthogonal array of particles } \\ \text { OAP }\end{array} \\ \text { CNS } & \begin{array}{l}\text { choral nervous system } \\ \text { cerebrospinal fluid }\end{array} \\ \text { CPE } & \text { multiple sclerosis } \\ \text { CSF } & \text { Alzheimer disease } \\ \text { MS } & \text { Parkinson disease } \\ \text { AD } & \text { Creutzfeldt-Jakob disease } \\ \text { PD } & \text { cerebral amyloid angiopathy } \\ \text { CJD } & \text { protein kinase A } \\ \text { CAA } & \text { protein kinase C } \\ \text { PKA } & \end{array}$

\section{References}

1. Amiry-Moghaddam, M.; Ottersen, O.P. The molecular basis of water transport in the brain. Nat. Rev. Neurosci. 2003, 4, 991-1001. [CrossRef] [PubMed]

2. Saadoun, S.; Papadopoulos, M.C. Aquaporin-4 in brain and spinal cord oedema. Neuroscience 2010, 168, 1036-1046. [CrossRef] [PubMed] 
3. Stokum, J.A.; Gerzanich, V.; Simard, J.M. Molecular pathophysiology of cerebral edema. J. Cereb. Blood Flow Metab. 2016, 36, 513-538. [CrossRef] [PubMed]

4. Harukuni, I.; Kirsch, J.R.; Bhardwaj, A. Cerebral resuscitation: Role of osmotherapy. J. Anesth. 2002, 16, 229-237. [CrossRef] [PubMed]

5. Vardjan, N.; Horvat, A.; Anderson, J.E.; Yu, D.; Croom, D.; Zeng, X.; Luznik, Z.; Kreft, M.; Teng, Y.D.; Kirov, S.A.; et al. Adrenergic activation attenuates astrocyte swelling induced by hypotonicity and neurotrauma. Glia 2016, 64, 1034-1049. [CrossRef] [PubMed]

6. Pangrsic, T.; Potokar, M.; Haydon, P.; Zorec, R.; Kreft, M. Astrocyte swelling leads to membrane unfolding, not membrane insertion. J. Neurochem. 2006, 99, 514-523. [CrossRef] [PubMed]

7. Thrane, A.S.; Rappold, P.M.; Fujita, T.; Torres, A.; Bekar, L.K.; Takano, T.; Peng, W.; Wang, F.; Thrane, V.R.; Enger, R.; et al. Critical role of aquaporin-4 (AQP4) in astrocytic $\mathrm{Ca}^{2+}$ signaling events elicited by cerebral edema. Proc. Natl. Acad. Sci. USA 2011, 108, 846-851. [CrossRef] [PubMed]

8. Risher, W.C.; Andrew, R.D.; Kirov, S.A. Real-time passive volume responses of astrocytes to acute osmotic and ischemic stress in cortical slices and in vivo revealed by two-photon microscopy. Glia 2009, 57, 207-221. [CrossRef] [PubMed]

9. Verkhratsky, A.; Butt, A.M. Glial Physiology and Pathophysiology; Wiley-Blackwell: Chichester, UK, 2013; p. 560.

10. Pekny, M.; Pekna, M. Astrocyte reactivity and reactive astrogliosis: Costs and benefits. Physiol. Rev. 2014, 94, 1077-1098. [CrossRef] [PubMed]

11. Nedergaard, M.; Ransom, B.; Goldman, S. New roles for astrocytes: Redefining the functional architecture of the brain. Trends Neurosci. 2003, 26, 523-530. [CrossRef] [PubMed]

12. Stevens, B. Neuron-astrocyte signaling in the development and plasticity of neural circuits. Neurosignals 2008, 16, 278-288. [CrossRef] [PubMed]

13. Haydon, P. Glia: Listening and talking to the synapse. Nat. Rev. Neurosci. 2001, 2, 185-193. [CrossRef] [PubMed]

14. Anderson, C.; Nedergaard, M. Astrocyte-mediated control of cerebral microcirculation. Trends Neurosci. 2003, 26, 340-344. [CrossRef]

15. Zonta, M.; Angulo, M.; Gobbo, S.; Rosengarten, B.; Hossmann, K.; Pozzan, T.; Carmignoto, G. Neuron-to-astrocyte signaling is central to the dynamic control of brain microcirculation. Nat. Neurosci. 2003, 6, 43-50. [CrossRef] [PubMed]

16. Gordon, G.; Mulligan, S.; MacVicar, B. Astrocyte control of the cerebrovasculature. Glia 2007, 55, $1214-1221$. [CrossRef] [PubMed]

17. Dong, Y.; Benveniste, E. Immune function of astrocytes. Glia 2001, 36, 180-190. [CrossRef] [PubMed]

18. De Keyser, J.; Zeinstra, E.; Frohman, E. Are astrocytes central players in the pathophysiology of multiple sclerosis? Arch. Neurol. 2003, 60, 132-136. [CrossRef] [PubMed]

19. Abbott, N.; Rönnbäck, L.; Hansson, E. Astrocyte-endothelial interactions at the blood-brain barrier. Nat. Rev. Neurosci. 2006, 7, 41-53. [CrossRef] [PubMed]

20. Ke, C.; Poon, W.S.; Ng, H.K.; Pang, J.C.; Chan, Y. Heterogeneous responses of aquaporin-4 in oedema formation in a replicated severe traumatic brain injury model in rats. Neurosci. Lett. 2001, 301, 21-24. [CrossRef]

21. Nase, G.; Helm, P.J.; Enger, R.; Ottersen, O.P. Water entry into astrocytes during brain edema formation. Glia 2008, 56, 895-902. [CrossRef] [PubMed]

22. Nedergaard, M.; Verkhratsky, A. Artifact versus reality-How astrocytes contribute to synaptic events. Glia 2012, 60, 1013-1023. [CrossRef] [PubMed]

23. Verkhratsky, A.; Nedergaard, M. Astroglial cradle in the life of the synapse. Philos. Trans. R Soc. Lond. B 2014, 369, 20130595. [CrossRef] [PubMed]

24. Parpura, V.; Zorec, R. Gliotransmission: Exocytotic release from astrocytes. Brain Res. Rev. 2010, 63, 83-92. [CrossRef] [PubMed]

25. Osborne, K.D.; Lee, W.; Malarkey, E.B.; Irving, A.J.; Parpura, V. Dynamic imaging of cannabinoid receptor 1 vesicular trafficking in cultured astrocytes. ASN Neuro 2009, 1. [CrossRef] [PubMed]

26. Kreft, M.; Stenovec, M.; Rupnik, M.; Grilc, S.; Krzan, M.; Potokar, M.; Pangrsic, T.; Haydon, P.; Zorec, R. Properties of $\mathrm{Ca}^{2+}$-dependent exocytosis in cultured astrocytes. Glia 2004, 46, 437-445. [CrossRef] [PubMed] 
27. Zorec, R.; Araque, A.; Carmignoto, G.; Haydon, P.G.; Verkhratsky, A.; Parpura, V. Astroglial excitability and gliotransmission: An appraisal of $\mathrm{Ca}^{2+}$ as a signalling route. ASN Neuro 2012, 4. [CrossRef] [PubMed]

28. Parpura, V.; Heneka, M.T.; Montana, V.; Oliet, S.H.; Schousboe, A.; Haydon, P.G.; Stout, R.F.; Spray, D.C.; Reichenbach, A.; Pannicke, T.; et al. Glial cells in (patho)physiology. J. Neurochem. 2012, 121, 4-27. [CrossRef] [PubMed]

29. Parpura, V.; Grubišić, V.; Verkhratsky, A. $\mathrm{Ca}^{2+}$ sources for the exocytotic release of glutamate from astrocytes. Biochim. Biophys. Acta 2011, 1813, 984-991. [CrossRef] [PubMed]

30. Gucek, A.; Vardjan, N.; Zorec, R. Exocytosis in astrocytes: Transmitter release and membrane signal regulation. Neurochem. Res. 2012, 37, 2351-2363. [CrossRef] [PubMed]

31. Potokar, M.; Kreft, M.; Pangrsic, T.; Zorec, R. Vesicle mobility studied in cultured astrocytes. Biochem. Biophys. Res. Commun. 2005, 329, 678-683. [CrossRef] [PubMed]

32. Potokar, M.; Kreft, M.; Li, L.; Daniel Andersson, J.; Pangrsic, T.; Chowdhury, H.; Pekny, M.; Zorec, R. Cytoskeleton and vesicle mobility in astrocytes. Traffic 2007, 8, 12-20. [CrossRef] [PubMed]

33. Vardjan, N.; Verkhratsky, A.; Zorec, R. Pathologic potential of astrocytic vesicle traffic: New targets to treat neurologic diseases? Cell Transplant. 2015, 24, 599-612. [CrossRef] [PubMed]

34. Potokar, M.; Vardjan, N.; Stenovec, M.; Gabrijel, M.; Trkov, S.; Jorgačevski, J.; Kreft, M.; Zorec, R. Astrocytic vesicle mobility in health and disease. Int. J. Mol. Sci. 2013, 14, 11238-11258. [CrossRef] [PubMed]

35. Azevedo, F.A.; Carvalho, L.R.; Grinberg, L.T.; Farfel, J.M.; Ferretti, R.E.; Leite, R.E.; Jacob Filho, W.; Lent, R.; Herculano-Houzel, S. Equal numbers of neuronal and nonneuronal cells make the human brain an isometrically scaled-up primate brain. J. Comp. Neurol. 2009, 513, 532-541. [CrossRef] [PubMed]

36. Bushong, E.A.; Martone, M.E.; Jones, Y.Z.; Ellisman, M.H. Protoplasmic astrocytes in CA1 stratum radiatum occupy separate anatomical domains. J. Neurosci. 2002, 22, 183-192. [PubMed]

37. Halassa, M.M.; Fellin, T.; Haydon, P.G. The tripartite synapse: Roles for gliotransmission in health and disease. Trends Mol. Med. 2007, 13, 54-63. [CrossRef] [PubMed]

38. Agre, P.; Preston, G.M.; Smith, B.L.; Jung, J.S.; Raina, S.; Moon, C.; Guggino, W.B.; Nielsen, S. Aquaporin CHIP: The archetypal molecular water channel. Am. J. Physiol. 1993, 265, F463-F476. [PubMed]

39. Nagelhus, E.A.; Ottersen, O.P. Physiological roles of aquaporin-4 in brain. Physiol. Rev. 2013, 93, $1543-1562$. [CrossRef] [PubMed]

40. Nielsen, S.; Nagelhus, E.A.; Amiry-Moghaddam, M.; Bourque, C.; Agre, P.; Ottersen, O.P. Specialized membrane domains for water transport in glial cells: High-resolution immunogold cytochemistry of aquaporin-4 in rat brain. J. Neurosci. 1997, 17, 171-180. [PubMed]

41. Agre, P.; Bonhivers, M.; Borgnia, M.J. The aquaporins, blueprints for cellular plumbing systems. J. Biol. Chem. 1998, 273, 14659-14662. [CrossRef] [PubMed]

42. Jung, J.S.; Bhat, R.V.; Preston, G.M.; Guggino, W.B.; Baraban, J.M.; Agre, P. Molecular characterization of an aquaporin cDNA from brain: Candidate osmoreceptor and regulator of water balance. Proc. Natl. Acad. Sci. USA 1994, 91, 13052-13056. [CrossRef] [PubMed]

43. Mulders, S.M.; Preston, G.M.; Deen, P.M.; Guggino, W.B.; van Os, C.H.; Agre, P. Water channel properties of major intrinsic protein of lens. J. Biol. Chem. 1995, 270, 9010-9016. [CrossRef] [PubMed]

44. Mulders, S.M.; van der Kemp, A.J.; Terlouw, S.A.; van Boxtel, H.A.; van Os, C.H.; Deen, P.M. The exchange of functional domains among aquaporins with different transport characteristics. Pflugers. Arch. 1998, 436, 599-607. [CrossRef] [PubMed]

45. Badaut, J.; Fukuda, A.M.; Jullienne, A.; Petry, K.G. Aquaporin and brain diseases. Biochim. Biophys. Acta 2014, 1840, 1554-1565. [CrossRef] [PubMed]

46. Bondy, C.; Chin, E.; Smith, B.L.; Preston, G.M.; Agre, P. Developmental gene expression and tissue distribution of the CHIP28 water-channel protein. Proc. Natl. Acad. Sci. USA 1993, 90, 4500-4504. [CrossRef] [PubMed]

47. Satoh, J.; Tabunoki, H.; Yamamura, T.; Arima, K.; Konno, H. Human astrocytes express aquaporin-1 and aquaporin-4 in vitro and in vivo. Neuropathology 2007, 27, 245-256. [CrossRef] [PubMed]

48. Badaut, J.; Hirt, L.; Granziera, C.; Bogousslavsky, J.; Magistretti, P.J.; Regli, L. Astrocyte-specific expression of aquaporin-9 in mouse brain is increased after transient focal cerebral ischemia. J. Cereb. Blood Flow Metab. 2001, 21, 477-482. [CrossRef] [PubMed] 
49. Badaut, J.; Petit, J.M.; Brunet, J.F.; Magistretti, P.J.; Charriaut-Marlangue, C.; Regli, L. Distribution of aquaporin 9 in the adult rat brain: Preferential expression in catecholaminergic neurons and in glial cells. Neuroscience 2004, 128, 27-38. [CrossRef] [PubMed]

50. Elkjaer, M.; Vajda, Z.; Nejsum, L.N.; Kwon, T.; Jensen, U.B.; Amiry-Moghaddam, M.; Frøkiaer, J.; Nielsen, S. Immunolocalization of AQP9 in liver, epididymis, testis, spleen, and brain. Biochem. Biophys. Res. Commun. 2000, 276, 1118-1128. [CrossRef] [PubMed]

51. Oshio, K.; Watanabe, H.; Song, Y.; Verkman, A.S.; Manley, G.T. Reduced cerebrospinal fluid production and intracranial pressure in mice lacking choroid plexus water channel aquaporin-1. FASEB J. 2005, 19, 76-78. [CrossRef] [PubMed]

52. Agre, P.; Brown, D.; Nielsen, S. Aquaporin water channels: Unanswered questions and unresolved controversies. Curr. Opin. Cell Biol. 1995, 7, 472-483. [CrossRef]

53. Preston, G.M.; Agre, P. Isolation of the cDNA for erythrocyte integral membrane protein of 28 kilodaltons: Member of an ancient channel family. Proc. Natl. Acad. Sci. USA 1991, 88, 11110-11114. [CrossRef] [PubMed]

54. Van Hoek, A.N.; Verkman, A.S. Functional reconstitution of the isolated erythrocyte water channel CHIP28. J. Biol. Chem. 1992, 267, 18267-18269. [PubMed]

55. Nielsen, S.; Smith, B.L.; Christensen, E.I.; Agre, P. Distribution of the aquaporin CHIP in secretory and resorptive epithelia and capillary endothelia. Proc. Natl. Acad. Sci. USA 1993, 90, 7275-7279. [CrossRef] [PubMed]

56. Anthony, T.L.; Brooks, H.L.; Boassa, D.; Leonov, S.; Yanochko, G.M.; Regan, J.W.; Yool, A.J. Cloned human aquaporin-1 is a cyclic GMP-gated ion channel. Mol. Pharmacol. 2000, 57, 576-588. [PubMed]

57. Boassa, D.; Stamer, W.D.; Yool, A.J. Ion channel function of aquaporin-1 natively expressed in choroid plexus. J. Neurosci. 2006, 26, 7811-7819. [CrossRef] [PubMed]

58. Saparov, S.M.; Kozono, D.; Rothe, U.; Agre, P.; Pohl, P. Water and ion permeation of aquaporin-1 in planar lipid bilayers. Major differences in structural determinants and stoichiometry. J. Biol. Chem. 2001, 276, 31515-31520. [CrossRef] [PubMed]

59. Hasegawa, H.; Lian, S.C.; Finkbeiner, W.E.; Verkman, A.S. Extrarenal tissue distribution of CHIP28 water channels by in situ hybridization and antibody staining. Am. J. Physiol. 1994, 266, C893-C903. [PubMed]

60. Nandasena, B.G.; Suzuki, A.; Aita, M.; Kawano, Y.; Nozawa-Inoue, K.; Maeda, T. Immunolocalization of aquaporin-1 in the mechanoreceptive Ruffini endings in the periodontal ligament. Brain Res. 2007, 1157, 32-40. [PubMed]

61. Oshio, K.; Watanabe, H.; Yan, D.; Verkman, A.S.; Manley, G.T. Impaired pain sensation in mice lacking Aquaporin-1 water channels. Biochem. Biophys. Res. Commun. 2006, 341, 1022-1028. [CrossRef] [PubMed]

62. Misawa, T.; Arima, K.; Mizusawa, H.; Satoh, J. Close association of water channel AQP1 with amyloid- $\beta$ deposition in Alzheimer disease brains. Acta Neuropathol. 2008, 116, 247-260. [CrossRef] [PubMed]

63. Arciénega, I.I.; Brunet, J.F.; Bloch, J.; Badaut, J. Cell locations for AQP1, AQP4 and 9 in the non-human primate brain. Neuroscience 2010, 167, 1103-1114. [CrossRef] [PubMed]

64. Shanahan, C.M.; Connolly, D.L.; Tyson, K.L.; Cary, N.R.; Osbourn, J.K.; Agre, P.; Weissberg, P.L. Aquaporin-1 is expressed by vascular smooth muscle cells and mediates rapid water transport across vascular cell membranes. J. Vasc. Res. 1999, 36, 353-362. [CrossRef] [PubMed]

65. Pérez, E.; Barrachina, M.; Rodríguez, A.; Torrejón-Escribano, B.; Boada, M.; Hernández, I.; Sánchez, M.; Ferrer, I. Aquaporin expression in the cerebral cortex is increased at early stages of Alzheimer disease. Brain Res. 2007, 1128, 164-174. [CrossRef] [PubMed]

66. Badaut, J.; Brunet, J.F.; Grollimund, L.; Hamou, M.F.; Magistretti, P.J.; Villemure, J.G.; Regli, L. Aquaporin 1 and aquaporin 4 expression in human brain after subarachnoid hemorrhage and in peritumoral tissue. Acta Neurochir. Suppl. 2003, 86, 495-498. [PubMed]

67. Costa, C.; Tortosa, R.; Rodríguez, A.; Ferrer, I.; Torres, J.M.; Bassols, A.; Pumarola, M. Aquaporin 1 and aquaporin 4 overexpression in bovine spongiform encephalopathy in a transgenic murine model and in cattle field cases. Brain Res. 2007, 1175, 96-106. [CrossRef] [PubMed]

68. Kim, J.E.; Ryu, H.J.; Yeo, S.I.; Seo, C.H.; Lee, B.C.; Choi, I.G.; Kim, D.S.; Kang, T.C. Differential expressions of aquaporin subtypes in astroglia in the hippocampus of chronic epileptic rats. Neuroscience 2009, 163, 781-789. [CrossRef] [PubMed] 
69. Rodríguez, A.; Pérez-Gracia, E.; Espinosa, J.C.; Pumarola, M.; Torres, J.M.; Ferrer, I. Increased expression of water channel aquaporin 1 and aquaporin 4 in Creutzfeldt-Jakob disease and in bovine spongiform encephalopathy-infected bovine-PrP transgenic mice. Acta Neuropathol. 2006, 112, 573-585. [CrossRef] [PubMed]

70. Saadoun, S.; Papadopoulos, M.C.; Davies, D.C.; Bell, B.A.; Krishna, S. Increased aquaporin 1 water channel expression in human brain tumours. Br. J. Cancer 2002, 87, 621-623. [CrossRef] [PubMed]

71. Nicchia, G.P.; Rossi, A.; Mola, M.G.; Procino, G.; Frigeri, A.; Svelto, M. Actin cytoskeleton remodeling governs aquaporin-4 localization in astrocytes. Glia 2008, 56, 1755-1766. [CrossRef] [PubMed]

72. Potokar, M.; Stenovec, M.; Jorgačevski, J.; Holen, T.; Kreft, M.; Ottersen, O.P.; Zorec, R. Regulation of AQP4 surface expression via vesicle mobility in astrocytes. Glia 2013, 61, 917-928. [CrossRef] [PubMed]

73. Zelenina, M. Regulation of brain aquaporins. Neurochem. Int. 2010, 57, 468-488. [CrossRef] [PubMed]

74. Han, Z.; Patil, R.V. Protein kinase A-dependent phosphorylation of aquaporin-1. Biochem. Biophys. Res. Commun. 2000, 273, 328-332. [CrossRef] [PubMed]

75. Zhang, W.; Zitron, E.; Hömme, M.; Kihm, L.; Morath, C.; Scherer, D.; Hegge, S.; Thomas, D.; Schmitt, C.P.; Zeier, M.; et al. Aquaporin-1 channel function is positively regulated by protein kinase C. J. Biol. Chem. 2007, 282, 20933-20940. [CrossRef] [PubMed]

76. Yang, B.; Verkman, A.S. Water and glycerol permeabilities of aquaporins 1-5 and MIP determined quantitatively by expression of epitope-tagged constructs in Xenopus oocytes. J. Biol. Chem. 1997, 272, 16140-16146. [CrossRef] [PubMed]

77. Patil, R.V.; Han, Z.; Wax, M.B. Regulation of water channel activity of aquaporin 1 by arginine vasopressin and atrial natriuretic peptide. Biochem. Biophys. Res. Commun. 1997, 238, 392-396. [CrossRef] [PubMed]

78. Marinelli, R.A.; Tietz, P.S.; Pham, L.D.; Rueckert, L.; Agre, P.; LaRusso, N.F. Secretin induces the apical insertion of aquaporin-1 water channels in rat cholangiocytes. Am. J. Physiol. 1999, 276, G280-G286. [PubMed]

79. Hasegawa, H.; Ma, T.; Skach, W.; Matthay, M.A.; Verkman, A.S. Molecular cloning of a mercurial-insensitive water channel expressed in selected water-transporting tissues. J. Biol. Chem. 1994, 269, 5497-5500. [PubMed]

80. Frigeri, A.; Gropper, M.A.; Umenishi, F.; Kawashima, M.; Brown, D.; Verkman, A.S. Localization of MIWC and GLIP water channel homologs in neuromuscular, epithelial and glandular tissues. J. Cell Sci. 1995, 108, 2993-3002. [PubMed]

81. Frigeri, A.; Gropper, M.A.; Turck, C.W.; Verkman, A.S. Immunolocalization of the mercurial-insensitive water channel and glycerol intrinsic protein in epithelial cell plasma membranes. Proc. Natl. Acad. Sci. USA 1995, 92, 4328-4331. [CrossRef] [PubMed]

82. Nagelhus, E.A.; Veruki, M.L.; Torp, R.; Haug, F.M.; Laake, J.H.; Nielsen, S.; Agre, P.; Ottersen, O.P. Aquaporin-4 water channel protein in the rat retina and optic nerve: Polarized expression in Müller cells and fibrous astrocytes. J. Neurosci. 1998, 18, 2506-2519. [PubMed]

83. Badaut, J.; Nehlig, A.; Verbavatz, J.; Stoeckel, M.; Freund-Mercier, M.J.; Lasbennes, F. Hypervascularization in the magnocellular nuclei of the rat hypothalamus: Relationship with the distribution of aquaporin- 4 and markers of energy metabolism. J. Neuroendocrinol. 2000, 12, 960-969. [CrossRef] [PubMed]

84. Badaut, J.; Verbavatz, J.M.; Freund-Mercier, M.J.; Lasbennes, F. Presence of aquaporin-4 and muscarinic receptors in astrocytes and ependymal cells in rat brain: A clue to a common function? Neurosci. Lett. 2000, 292, 75-78. [CrossRef]

85. Rash, J.E.; Yasumura, T.; Hudson, C.S.; Agre, P.; Nielsen, S. Direct immunogold labeling of aquaporin-4 in square arrays of astrocyte and ependymocyte plasma membranes in rat brain and spinal cord. Proc. Natl. Acad. Sci. USA 1998, 95, 11981-11986. [CrossRef] [PubMed]

86. Hirt, B.; Gleiser, C.; Eckhard, A.; Mack, A.F.; Müller, M.; Wolburg, H.; Löwenheim, H. All functional aquaporin-4 isoforms are expressed in the rat cochlea and contribute to the formation of orthogonal arrays of particles. Neuroscience 2011, 189, 79-92. [CrossRef] [PubMed]

87. Takumi, Y.; Nagelhus, E.A.; Eidet, J.; Matsubara, A.; Usami, S.; Shinkawa, H.; Nielsen, S.; Ottersen, O.P. Select types of supporting cell in the inner ear express aquaporin-4 water channel protein. Eur. J. Neurosci. 1998, 10, 3584-3595. [CrossRef] [PubMed]

88. Frigeri, A.; Nicchia, G.P.; Verbavatz, J.M.; Valenti, G.; Svelto, M. Expression of aquaporin-4 in fast-twitch fibers of mammalian skeletal muscle. J. Clin. Investig. 1998, 102, 695-703. [CrossRef] [PubMed] 
89. Moe, S.E.; Sorbo, J.G.; Sogaard, R.; Zeuthen, T.; Petter Ottersen, O.; Holen, T. New isoforms of rat aquaporin-4. Genomics 2008, 91, 367-377. [CrossRef] [PubMed]

90. Neely, J.D.; Christensen, B.M.; Nielsen, S.; Agre, P. Heterotetrameric composition of aquaporin-4 water channels. Biochemistry 1999, 38, 11156-11163. [CrossRef] [PubMed]

91. De Bellis, M.; Pisani, F.; Mola, M.G.; Basco, D.; Catalano, F.; Nicchia, G.P.; Svelto, M.; Frigeri, A. A novel human aquaporin-4 splice variant exhibits a dominant-negative activity: A new mechanism to regulate water permeability. Mol. Biol. Cell 2014, 25, 470-480. [CrossRef] [PubMed]

92. Lu, M.; Lee, M.D.; Smith, B.L.; Jung, J.S.; Agre, P.; Verdijk, M.A.; Merkx, G.; Rijss, J.P.; Deen, P.M. The human AQP4 gene: Definition of the locus encoding two water channel polypeptides in brain. Proc. Natl. Acad. Sci. USA 1996, 93, 10908-10912. [CrossRef] [PubMed]

93. Yang, B.; Ma, T.; Verkman, A.S. cDNA cloning, gene organization, and chromosomal localization of a human mercurial insensitive water channel. Evidence for distinct transcriptional units. J. Biol. Chem. 1995, 270, 22907-22913. [CrossRef] [PubMed]

94. Furman, C.S.; Gorelick-Feldman, D.A.; Davidson, K.G.; Yasumura, T.; Neely, J.D.; Agre, P.; Rash, J.E. Aquaporin-4 square array assembly: Opposing actions of M1 and M23 isoforms. Proc. Natl. Acad. Sci. USA 2003, 100, 13609-13614. [CrossRef] [PubMed]

95. Crane, J.M.; van Hoek, A.N.; Skach, W.R.; Verkman, A.S. Aquaporin-4 dynamics in orthogonal arrays in live cells visualized by quantum dot single particle tracking. Mol. Biol. Cell 2008, 19, 3369-3378. [CrossRef] [PubMed]

96. Rossi, A.; Crane, J.M.; Verkman, A.S. Aquaporin-4 Mz isoform: Brain expression, supramolecular assembly and neuromyelitis optica antibody binding. Glia 2011, 59, 1056-1063. [CrossRef] [PubMed]

97. Sørbø, J.G.; Fleckenstein, B.; Ottersen, O.P.; Holen, T. Small-scale purification and mass spectrometry analysis reveal a third aquaporin-4 protein isoform of $36 \mathrm{kDa}$ in rat brain. J. Neurosci. Methods 2012, 211, 31-39. [CrossRef] [PubMed]

98. Sorbo, J.G.; Moe, S.E.; Ottersen, O.P.; Holen, T. The molecular composition of square arrays. Biochemistry 2008, 47, 2631-2637. [CrossRef] [PubMed]

99. Madrid, R.; Le Maout, S.; Barrault, M.B.; Janvier, K.; Benichou, S.; Mérot, J. Polarized trafficking and surface expression of the AQP4 water channel are coordinated by serial and regulated interactions with different clathrin-adaptor complexes. EMBO J. 2001, 20, 7008-7021. [CrossRef] [PubMed]

100. Hub, J.S.; de Groot, B.L.; Grubmüller, H.; Groenhof, G. Quantifying artifacts in Ewald simulations of inhomogeneous systems with a net charge. J. Chem. Theory Comput. 2014, 10, 381-390. [CrossRef] [PubMed]

101. Cheng, A.; van Hoek, A.N.; Yeager, M.; Verkman, A.S.; Mitra, A.K. Three-dimensional organization of a human water channel. Nature 1997, 387, 627-630. [PubMed]

102. Marples, D.; Schroer, T.A.; Ahrens, N.; Taylor, A.; Knepper, M.A.; Nielsen, S. Dynein and dynactin colocalize with AQP2 water channels in intracellular vesicles from kidney collecting duct. Am. J. Physiol. 1998, 274, F384-F394. [PubMed]

103. King, L.S.; Kozono, D.; Agre, P. From structure to disease: The evolving tale of aquaporin biology. Nat. Rev. Mol. Cell Biol. 2004, 5, 687-698. [CrossRef] [PubMed]

104. Yasui, M.; Kwon, T.H.; Knepper, M.A.; Nielsen, S.; Agre, P. Aquaporin-6: An intracellular vesicle water channel protein in renal epithelia. Proc. Natl. Acad. Sci. USA 1999, 96, 5808-5813. [CrossRef] [PubMed]

105. Yasui, M.; Hazama, A.; Kwon, T.H.; Nielsen, S.; Guggino, W.B.; Agre, P. Rapid gating and anion permeability of an intracellular aquaporin. Nature 1999, 402, 184-187. [PubMed]

106. Gorelick, D.A.; Praetorius, J.; Tsunenari, T.; Nielsen, S.; Agre, P. Aquaporin-11: A channel protein lacking apparent transport function expressed in brain. BMC Biochem. 2006, 7, 14. [CrossRef] [PubMed]

107. Takahashi, S.; Muta, K.; Sonoda, H.; Kato, A.; Abdeen, A.; Ikeda, M. The role of cysteine 227 in subcellular localization, water permeability, and multimerization of aquaporin-11. FEBS Open Bio 2014, 4, 315-320. [CrossRef] [PubMed]

108. Hiroaki, Y.; Tani, K.; Kamegawa, A.; Gyobu, N.; Nishikawa, K.; Suzuki, H.; Walz, T.; Sasaki, S.; Mitsuoka, K.; Kimura, K.; et al. Implications of the aquaporin-4 structure on array formation and cell adhesion. J. Mol. Biol. 2006, 355, 628-639. [CrossRef] [PubMed]

109. Verbavatz, J.M.; Ma, T.; Gobin, R.; Verkman, A.S. Absence of orthogonal arrays in kidney, brain and muscle from transgenic knockout mice lacking water channel aquaporin-4. J. Cell Sci. 1997, 110, 2855-2860. [PubMed] 
110. Rash, J.E.; Davidson, K.G.; Yasumura, T.; Furman, C.S. Freeze-fracture and immunogold analysis of aquaporin-4 (AQP4) square arrays, with models of AQP4 lattice assembly. Neuroscience 2004, 129, 915-934. [CrossRef] [PubMed]

111. Tajima, M.; Crane, J.M.; Verkman, A.S. Aquaporin-4 (AQP4) associations and array dynamics probed by photobleaching and single-molecule analysis of green fluorescent protein-AQP4 chimeras. J. Biol. Chem. 2010, 285, 8163-8170. [CrossRef] [PubMed]

112. Crane, J.M.; Bennett, J.L.; Verkman, A.S. Live cell analysis of aquaporin-4 M1/M23 interactions and regulated orthogonal array assembly in glial cells. J. Biol. Chem. 2009, 284, 35850-35860. [CrossRef] [PubMed]

113. Crane, J.M.; Verkman, A.S. Determinants of aquaporin- 4 assembly in orthogonal arrays revealed by live-cell single-molecule fluorescence imaging. J. Cell Sci. 2009, 122, 813-821. [CrossRef] [PubMed]

114. Iliff, J.J.; Wang, M.; Liao, Y.; Plogg, B.A.; Peng, W.; Gundersen, G.A.; Benveniste, H.; Vates, G.E.; Deane, R.; Goldman, S.A.; et al. A paravascular pathway facilitates CSF flow through the brain parenchyma and the clearance of interstitial solutes, including amyloid $\beta$. Sci. Transl. Med. 2012, 4, 147ra111. [CrossRef] [PubMed]

115. Silberstein, C.; Bouley, R.; Huang, Y.; Fang, P.; Pastor-Soler, N.; Brown, D.; van Hoek, A.N. Membrane organization and function of M1 and M23 isoforms of aquaporin-4 in epithelial cells. Am. J. Physiol. Ren. Physiol. 2004, 287, F501-F511. [CrossRef] [PubMed]

116. Yamamoto, N.; Sobue, K.; Fujita, M.; Katsuya, H.; Asai, K. Differential regulation of aquaporin-5 and -9 expression in astrocytes by protein kinase A. Brain Res. Mol. Brain Res. 2002, 104, 96-102. [CrossRef]

117. Assentoft, M.; Kaptan, S.; Fenton, R.A.; Hua, S.Z.; de Groot, B.L.; MacAulay, N. Phosphorylation of rat aquaporin-4 at Ser ${ }^{111}$ is not required for channel gating. Glia 2013, 61, 1101-1112. [CrossRef] [PubMed]

118. McCoy, E.S.; Haas, B.R.; Sontheimer, H. Water permeability through aquaporin-4 is regulated by protein kinase $\mathrm{C}$ and becomes rate-limiting for glioma invasion. Neuroscience 2010, 168, 971-981. [CrossRef] [PubMed]

119. Yamamoto, N.; Sobue, K.; Miyachi, T.; Inagaki, M.; Miura, Y.; Katsuya, H.; Asai, K. Differential regulation of aquaporin expression in astrocytes by protein kinase C. Brain Res. Mol. Brain Res. 2001, 95, 110-116. [CrossRef]

120. Stenovec, M.; Trkov, S.; Lasič, E.; Terzieva, S.; Kreft, M.; Rodríguez Arellano, J.J.; Parpura, V.; Verkhratsky, A.; Zorec, R. Expression of familial Alzheimer disease presenilin 1 gene attenuates vesicle traffic and reduces peptide secretion in cultured astrocytes devoid of pathologic tissue environment. Glia 2016, 64, 317-329. [CrossRef] [PubMed]

121. Rossi, A.; Baumgart, F.; van Hoek, A.N.; Verkman, A.S. Post-Golgi supramolecular assembly of aquaporin-4 in orthogonal arrays. Traffic 2012, 13, 43-53. [CrossRef] [PubMed]

122. Rossi, A.; Moritz, T.J.; Ratelade, J.; Verkman, A.S. Super-resolution imaging of aquaporin-4 orthogonal arrays of particles in cell membranes. J. Cell Sci. 2012, 125, 4405-4412. [CrossRef] [PubMed]

123. Pisani, F.; Rossi, A.; Nicchia, G.P.; Svelto, M.; Frigeri, A. Translational regulation mechanisms of aquaporin-4 supramolecular organization in astrocytes. Glia 2011, 59, 1923-1932. [CrossRef] [PubMed]

124. Suzuki, H.; Nishikawa, K.; Hiroaki, Y.; Fujiyoshi, Y. Formation of aquaporin-4 arrays is inhibited by palmitoylation of N-terminal cysteine residues. Biochim. Biophys. Acta 2008, 1778, 1181-1189. [CrossRef] [PubMed]

125. Eid, T.; Lee, T.S.; Thomas, M.J.; Amiry-Moghaddam, M.; Bjørnsen, L.P.; Spencer, D.D.; Agre, P.; Ottersen, O.P.; de Lanerolle, N.C. Loss of perivascular aquaporin 4 may underlie deficient water and $\mathrm{K}^{+}$homeostasis in the human epileptogenic hippocampus. Proc. Natl. Acad. Sci. USA 2005, 102, 1193-1198. [CrossRef] [PubMed]

126. Lee, T.S.; Eid, T.; Mane, S.; Kim, J.H.; Spencer, D.D.; Ottersen, O.P.; de Lanerolle, N.C. Aquaporin-4 is increased in the sclerotic hippocampus in human temporal lobe epilepsy. Acta Neuropathol. 2004, 108, 493-502. [CrossRef] [PubMed]

127. Moftakhar, P.; Lynch, M.D.; Pomakian, J.L.; Vinters, H.V. Aquaporin expression in the brains of patients with or without cerebral amyloid angiopathy. J. Neuropathol. Exp. Neurol. 2010, 69, 1201-1209. [CrossRef] [PubMed]

128. Hoshi, A.; Yamamoto, T.; Shimizu, K.; Ugawa, Y.; Nishizawa, M.; Takahashi, H.; Kakita, A. Characteristics of aquaporin expression surrounding senile plaques and cerebral amyloid angiopathy in Alzheimer disease. J. Neuropathol. Exp. Neurol. 2012, 71,750-759. [CrossRef] [PubMed] 
129. Yang, J.; Lunde, L.K.; Nuntagij, P.; Oguchi, T.; Camassa, L.M.; Nilsson, L.N.; Lannfelt, L.; Xu, Y.; Amiry-Moghaddam, M.; Ottersen, O.P.; et al. Loss of astrocyte polarization in the tg-ArcSwe mouse model of Alzheimer's disease. J. Alzheimers Dis. 2011, 27, 711-722. [PubMed]

130. Aoki-Yoshino, K.; Uchihara, T.; Duyckaerts, C.; Nakamura, A.; Hauw, J.J.; Wakayama, Y. Enhanced expression of aquaporin 4 in human brain with inflammatory diseases. Acta Neuropathol. 2005, 110, 281-288. [CrossRef] [PubMed]

131. Saadoun, S.; Papadopoulos, M.C.; Davies, D.C.; Krishna, S.; Bell, B.A. Aquaporin-4 expression is increased in oedematous human brain tumours. J. Neurol. Neurosurg. Psychiatry 2002, 72, 262-265. [CrossRef] [PubMed]

132. Aoki, K.; Uchihara, T.; Tsuchiya, K.; Nakamura, A.; Ikeda, K.; Wakayama, Y. Enhanced expression of aquaporin 4 in human brain with infarction. Acta Neuropathol. 2003, 106, 121-124. [CrossRef] [PubMed]

133. Tsukaguchi, H.; Shayakul, C.; Berger, U.V.; Mackenzie, B.; Devidas, S.; Guggino, W.B.; van Hoek, A.N.; Hediger, M.A. Molecular characterization of a broad selectivity neutral solute channel. J. Biol. Chem. 1998, 273, 24737-24743. [CrossRef] [PubMed]

134. Tsukaguchi, H.; Weremowicz, S.; Morton, C.C.; Hediger, M.A. Functional and molecular characterization of the human neutral solute channel aquaporin-9. Am. J. Physiol. 1999, 277, F685-F696. [PubMed]

135. Ishibashi, K.; Kuwahara, M.; Gu, Y.; Tanaka, Y.; Marumo, F.; Sasaki, S. Cloning and functional expression of a new aquaporin (AQP9) abundantly expressed in the peripheral leukocytes permeable to water and urea, but not to glycerol. Biochem. Biophys. Res. Commun. 1998, 244, 268-274. [CrossRef] [PubMed]

136. Tan, G.; Sun, S.Q.; Yuan, D.L. Expression of the water channel protein aquaporin-9 in human astrocytic tumours: Correlation with pathological grade. J. Int. Med. Res. 2008, 36, 777-782. [CrossRef] [PubMed]

137. Jelen, S.; Parm Ulhøi, B.; Larsen, A.; Frøkiær, J.; Nielsen, S.; Rützler, M. AQP9 expression in glioblastoma multiforme tumors is limited to a small population of astrocytic cells and $\mathrm{CD}^{+} 5^{+} / \mathrm{CalB}^{+}$leukocytes. PLoS ONE 2013, 8, e75764. [CrossRef] [PubMed]

138. Oshio, K.; Binder, D.K.; Yang, B.; Schecter, S.; Verkman, A.S.; Manley, G.T. Expression of aquaporin water channels in mouse spinal cord. Neuroscience 2004, 127, 685-693. [CrossRef] [PubMed]

139. Nicchia, G.P.; Frigeri, A.; Nico, B.; Ribatti, D.; Svelto, M. Tissue distribution and membrane localization of aquaporin-9 water channel: Evidence for sex-linked differences in liver. J. Histochem. Cytochem. 2001, 49, 1547-1556. [CrossRef] [PubMed]

140. Amiry-Moghaddam, M.; Lindland, H.; Zelenin, S.; Roberg, B.A.; Gundersen, B.B.; Petersen, P.; Rinvik, E.; Torgner, I.A.; Ottersen, O.P. Brain mitochondria contain aquaporin water channels: Evidence for the expression of a short AQP9 isoform in the inner mitochondrial membrane. FASEB J. 2005, 19, 1459-1467. [CrossRef] [PubMed]

141. Badaut, J.; Brunet, J.F.; Guérin, C.; Regli, L.; Pellerin, L. Alteration of glucose metabolism in cultured astrocytes after AQP9-small interference RNA application. Brain Res. 2012, 1473, 19-24. [CrossRef] [PubMed] 